\title{
Exposure to allergens of different cattle breeds and their relevance in occupational allergy
}

\author{
Astrid R. R. Heutelbeck • Carsten Junghans • \\ Hermann Esselmann · Ernst Hallier · Thomas G. Schulz
}

Received: 24 July 2008 / Accepted: 18 January 2009 / Published online: 24 February 2009

(C) The Author(s) 2009. This article is published with open access at Springerlink.com

\begin{abstract}
Introduction Cattle are an important source of allergens in the working area of farmers. Asthma caused by cow allergens is a significant occupational problem. Yet in allergological testing, the results of in vivo and in vitro diagnostic tests are often inconsistent even in cases with clearly cattle-related symptoms.

Objectives and methods The aim of this study was to investigate four different commercial cow allergen extracts and to compare them with self prepared extracts of different cattle breeds by means of SDS-PAGE and immunoblotting using the sera of 42 German farmers with asthma and rhino-conjunctivitis caused by cattle contact.
\end{abstract}

\footnotetext{
A. R. R. Heutelbeck $(\bowtie) \cdot$ C. Junghans · E. Hallier · T. G. Schulz Department of Occupational Health, Georg-August-University, Waldweg 37, 37073 Göttingen, Germany

e-mail: aheutel@gwdg.de

E. Hallier

e-mail: ehallie@gwdg.de

T. G. Schulz

e-mail: thomas.schulz@bfr.bund.de

H. Esselmann

Department of Psychiatry, Georg-August-University,

Von-Siebold-Str. 5, 37073 Göttingen, Germany

e-mail: Hermann.Esselmann@uni-due.de

Present Address:

H. Esselmann

Department of Psychiatry and Psychotherapy,

Rhine State Hospital Essen, University of Duisburg-Essen,

Virchowstr. 174, 45147 Essen, Germany

Present Address:

T. G. Schulz

Federal Institute for Risk Assessment,

Thielallee 88-92, 14195 Berlin, Germany
}

Results The commercial extracts investigated in this study showed only minor differences in protein pattern. Using sera in immunoblotting experiments distinct bands were found for all symptomatic farmers, even in 13 farmers with a negative result in commercially available serological allergy tests. Bands with molecular weights in the range between about 11 and $67 \mathrm{kDa}$ were observed; reactivity with the major allergen Bos d 2 at about $20 \mathrm{kDa}$ was detected in all farmers, although it was not the strongest band in all cases. Conclusions We demonstrate for the first time the allergenic relevance of additional proteins with molecular weights of $14,30,55$ and approx. $67-97 \mathrm{kDa}$ in more than $50 \%$ of farmers with cattle related symptoms. One of our most striking results was that $32 \%$ of the investigated farmers with cattle related symptoms showed negative results with commercial serological tests but distinct reactions with cow allergen in immunoblotting experiments. The Bos d 2 content in hair showed differences between certain breeds whereas German Brown and Simmental had particularly higher quantities of Bos d 2 in their hair than breeds such as Holstein-Friesian. These results strongly support the following recommendation: test results with commercial extracts that are contradictory to the clinical symptoms should be supplemented by skin tests using extracts of the hair of the farmers' own cattle.

Keywords Occupational allergy · Cattle allergen . Diagnosis · Bos d 2

\section{Introduction}

Cattle are an important source of allergens in the working environment of farmers. Asthma caused by cow allergens is a significant occupational problem in many countries 
(Heutelbeck et al. 2007; Karjalainen et al. 2000; Reijula and Patterson 1994). Unlike many other chronic diseases which primarily affect older people, asthma disproportionately affects younger people in their working age. The diagnosis of an occupational asthma caused by cattle allergen has grave economic and occupational consequences for the affected worker, especially in the light of the large number of young patients (Heutelbeck et al. 2007). This constitutes a paramount public health concern, as up to $40 \%$ are consequently rated as partially employment-disabled (Blanc et al. 1993, 1996). A diagnosis in an early state of sensitization might be helpful to avoid clinical manifestation of an allergic disease, if essential prevention strategies were initiated.

In contrast to extracts from cat or dog allergens, only little is known about the composition and potency of cattle allergens. Crossed-immunoelectrophoresis extracts of cow hair and dander consisted of at least 17 different proteins whereas three major allergenic proteins were identified in cow dander as well as in other tissues and body fluids (Prahl 1980, 1981; Prahl et al. 1978, 1982). One of the large protein bands detected in all extracts with an estimated molecular weight of $20 \mathrm{kDa}$ has been described previously as major allergen Bos d 2 (Prahl et al. 1982; Rautiainen et al. 1997; Ylönen et al. 1992a, b).

As to the allergological diagnosis of a cattle allergy, results of in vivo and in vitro tests are often inconsistent even in cases with clearly cattle-related symptoms. Clinical experience confirms previously published observations that allergy tests with commercial cattle allergen extracts occasionally show only slightly positive or even negative results even though the tested patients showed clearly cattle-related clinical symptoms (Wortmann 1984; Fuchs et al. 1981). Positive reactions with hair of the patients` own cattle have been reported, without a corresponding result using commercial extracts (Heutelbeck et al. 2007). In a number of cases, allergy tests with extracts of the hair of the patients' cattle or of cattle of the same breed can thus yield better results. Similar phenomena were described elsewhere (Prahl et al. 1978; Ylönen et al. 1990). In some patients commercial test preparations of cow allergen did not confirm obviously cow related symptoms. The results appeared to be influenced by the composition of the cattle allergen extracts, possibly due to a lack of certain important allergens in the applied extract or breed-specific allergen components.

The aim of the present study was to assess the multiracial cattle allergens by investigating the respective protein patterns and their allergological relevance in symptomatic farmers as well as the Bos d 2 levels in hair of a range of relevant cattle breeds.

\section{Materials and methods}

Characterization of the cattle allergic farmers

The sera of 42 farmers (26 male, 16 female; age $25-74$, mean 52.2, median 52 years) with cattle-related symptoms (29 upper airway symptoms such as allergic rhinitis, 37 asthmatic symptoms, 19 skin symptoms such as itching, eczema and urtica) were investigated. Most of the farmers kept cattle races such as Holstein-Friesian (HF, $n=23$ ), mainly in the northern parts of Germany; in the southern parts of Germany, the main cattle races were German Simmental (GS, $n=15$ ) and German Brown (GB, $n=14)$. Only a few farmers kept races uncommon to Germany such as German Red Pied (GRP, $n=7$ ), Charolais (Ch, $n=5$ ), Blonde Aquitaine (BA, $n=2$ ), Jersey (J, $n=1$ ), or Limou$\sin (\mathrm{L}, n=1)$. Additionally, two non-farming control subjects who had never shown allergic symptoms or reactions against animal-derived antigens were included in the study.

The detection of specific IgE antibodies was performed using CAP RAST ${ }^{\circledR}$ (CAP-System, Pharmacia Diagnostics, present name: Phadia, Freiburg, Germany).

\section{Commercial cow allergen extracts}

Raw material from four different manufacturers of skin test extracts (Allergopharma, Reinbek near Hamburg, Germany; ALK-Scherax, Hamburg, Germany; Bencard, Munich, Germany; HAL, Düsseldorf, Germany, hereafter referred to as A, B, C, and D, respectively) was used. After reconstitution of the lyophilized raw material in distilled water, the total protein content was about $4 \mathrm{mg} / \mathrm{ml}$.

\section{Self-made cow allergen extracts}

Cattle selected for this study were all healthy to avoid a possible influence of pathologic conditions on the cattle allergen production. Farmers were instructed to cut the cattle hair close to the skin without visible contamination. The hair of cattle of different breeds was used, including samples of the most common cattle breeds in Germany, namely Holstein-Friesian, German Brown, Limousin, Charolais, German Simmental, Blonde d'Aquitaine and German Red Pied. Two grams of hair were extracted with $20 \mathrm{ml}$ of $0.125 \mathrm{M} \mathrm{NH}_{4} \mathrm{HCO}_{3}$ for $24-72 \mathrm{~h}$ at $4^{\circ} \mathrm{C}$, following centrifugation. An incubation period of $44 \mathrm{~h}$ was found to yield optimum results in protein content and SDS-PAGE separation (data not shown).

\section{Protein determination}

Protein content was determined using the bicinchonic acid procedure as described by Pierce Chemicals, Rockford, 
USA. The results were verified using different dilutions of each sample. The samples were lyophilised and reconstituted in $10 \%$ of the original volume, then stored at $-20^{\circ} \mathrm{C}$. It was verified that the lyophilized extracts did not show any differences concerning total protein content or SDS-PAGE analysis compared to the unlyophilized extracts (data not shown).

\section{SDS-PAGE/immunoblot}

The detection of the allergenic proteins in the extracts was performed by immunoblotting. Proteins were separated with SDS-PAGE using 15\% gels to achieve optimum separation of proteins in the relative molecular mass between $6 \mathrm{kDa}$ and about $60 \mathrm{kDa}$. Molecular weights (MW) were estimated by comparison to commercial MW standard mixtures ("SDS Low Range" from Bio-Rad, Munich, Germany; "Multi Mark" from Invitrogen, Karlsruhe, Germany). Immunoblot experiments were performed for every farmer with extracts from the lyophilised raw material used for the commercial extracts and from the hair of the cattle which were kept on their specific farm.

Equal amounts of extracts with concentrations of $1 \mathrm{mg}$ protein per ml were applied to SDS-PAGE which was conducted at a constant voltage $(150 \mathrm{~V})$ for $90-100 \mathrm{~min}$. For the investigation of the protein patterns, the gels were stained with Coomassie blue. The molecular weights of the corresponding allergens were estimated relative to the standard marker proteins.

After separation by SDS-PAGE on a $15 \%$ gel, proteins were transferred onto polyvinylidine difluoride (PVDF) membranes in a semi-dry blot apparatus. Membranes were incubated over night in Roti Block solution (Roth, Karlsruhe, Germany) to block non-specific binding sites and were finally incubated with two serum dilutions (1:5 and 1:20) for $1 \mathrm{~h}$ at room temperature. After washing five times with Tris-buffered saline (TBS, pH 7.5) containing $0.1 \%$ Tween, anti-human-IgE monoclonal antibodies diluted 1: 1000 in Roti Block solution coupled with alkaline phosphatase [Sigma-Aldrich, Steinheim, Germany (Art.No. A3076)] were added for $1 \mathrm{~h}$ at room temperature. After washing five times with TBS containing $0.1 \%$ Tween, the detection of alkaline phosphatase was performed using the NBT ( $p$-nitro blue tetrazolium chloride)/BCIP (5-bromo-4chloro-3-indoyl phosphate $p$-toluidine salt) system (BioRad, Munich, Germany) according to the recommendations of the manufacturer. The development was completed by removal of the solution and washing with water. The membranes were dried and scanned. Each sample was investigated at least twice in independent experiments. Control experiments were performed with commercial and self prepared extracts and serum samples from two non-farming control subjects who had never shown allergic symptoms or reactions against animal-derived antigens.
Bos d 2 quantification

Using ELISA the cattle allergen Bos d 2 was quantified (modified according to Virtanen et al. 1986, 1988) as follows: NUNC F96 Maxisorp plates were coated overnight with anti-Bos d 2 (obtained from Tuomas Virtanen, Department of Clinical Microbiology, University of Kuopio, Finland) at a concentration of $1.5 \mu \mathrm{l} / \mathrm{ml}$. Plates were washed with phosphate-buffered saline (PBS, pH 7.4) containing $0.05 \%$ Tween 20 , blocked with diluent (PBS containing 0.05\% Tween 20, 1\% BSA) and aspirated. The Bos d 2 standard (obtained from Tuomas Virtanen, Department of Clinical Microbiology, University of Kuopio, Finland) ranged from $100 \mathrm{ng}$ up to $0.2 \mathrm{ng} / \mathrm{ml}$ and samples were diluted (PBS containing $0.05 \%$ Tween $20,0.1 \%$ BSA), and incubated (100 $\mu \mathrm{l} /$ well) at room temperature. After washing, $100 \mu \mathrm{l}$ of the biotinylated anti-Bos d 2 (obtained from Tuomas Virtanen, Department of Clinical Microbiology, University of Kuopio, Finland) at the concentration of $0.015 \mu \mathrm{g} / \mathrm{ml}$ was added to the wells and incubated for $1 \mathrm{~h}$ at room temperature. After washing, Streptavidin-horseradish peroxidase (Amersham Biosiences) 1:8,000 diluted in PBS containing $0.05 \%$ Tween 20 and $0.1 \%$ BSA was added to the wells ( $100 \mu \mathrm{l} /$ well $)$ and incubated for $30 \mathrm{~min}$ at room temperature. $100 \mu \mathrm{l}$ of an $\mathrm{ABTS} / \mathrm{H}_{2} \mathrm{O}_{2}$ substrate solution (2,2' -azino-bis(3-ethylbenzthiazoline-6-sulfonic acid) (Roche Molecular Biochemicals, Mannheim, Germany) was added to reveal the reaction. The optical densities were read with a $405 \mathrm{~nm}$ filter after $30 \mathrm{~min}$. Results are given in $\mu \mathrm{g} / \mathrm{g}$ hair.

\section{Results}

Characterization of the cattle allergic farmers

Exactly $32 \%(n=13)$ showed negative and further $14 \%$ $(n=6)$ slightly positive test results (CAP-RAST class 1$)$ despite clearly cattle related airways symptoms. The remaining symptomatic farmers showed specific IgE antibodies against cattle allergen. In detail 11 farmers showed an amount of specific IgE antibodies against cattle allergen corresponding to CAP-RAST class 2 (26\%), three farmers CAP-RAST class $3(7 \%)$, four farmers CAPRAST class $4(10 \%)$, one farmer CAP-RAST class $5(2 \%)$ and one farmer CAP-RAST class $6(2 \%)$. The total IgE ranged from 2 up to $2,883 \mathrm{kU} / \mathrm{l}$ (mean 367, median $173 \mathrm{kU} / \mathrm{l})$, whereas $64.3 \%(n=27)$ showed total IgE values greater than $100 \mathrm{kU} / \mathrm{l}$ (Zetterström and Johansson 1981). The characterization of the farmers is presented in Table 1. In the two control subjects no specific IgE reactivity was detectable. 
Table 1 Characterization of the 42 farmers (26 male m, 16 female f) with cattle related symptoms [upper airways (UA), asthma (AB), skin] with respect to the different breeds of cattle [Holstein-Friesian (HF), German Brown (GB), Limousin (L), Charolais (Ch), German Simmental (GS), Blonde d'Aquitaine (BA) and German Red Pied (GRP), Jersey (J)]

\begin{tabular}{|c|c|c|c|c|c|c|}
\hline $\begin{array}{l}\text { Farmer } \\
\text { No. }\end{array}$ & $\begin{array}{l}\text { Age } \\
\text { (years) }\end{array}$ & Sex & $\begin{array}{l}\text { Cattle related } \\
\text { symptoms }\end{array}$ & $\begin{array}{l}\text { Result } \\
\text { pharmacia } \\
\text { CAP RAST }\end{array}$ & $\begin{array}{l}\text { Total } \\
\text { IgE kU/1 }\end{array}$ & Breeds of cattle \\
\hline 1 & 67 & $\mathrm{w}$ & $\mathrm{UA}, \mathrm{AB}$ & 0 & 32 & HF, GRP, GS, GB \\
\hline 2 & 64 & $\mathrm{~m}$ & $\mathrm{AB}$ & 0 & 67 & $\mathrm{HF}, \mathrm{Ch}, \mathrm{GRP}, \mathrm{J}$ \\
\hline 3 & 32 & $\mathrm{~m}$ & $\mathrm{UA}, \mathrm{AB}$ & 2 & 223 & $\mathrm{HF}$ \\
\hline 4 & 37 & $\mathrm{~m}$ & $\mathrm{UA}, \mathrm{AB}$ & 2 & 40 & $\mathrm{HF}$ \\
\hline 5 & 48 & $\mathrm{w}$ & $\mathrm{UA}, \mathrm{AB}$ & 0 & 121 & $\mathrm{HF}$ \\
\hline 6 & 60 & $\mathrm{w}$ & UA, skin & 1 & 9 & $\mathrm{HF}$ \\
\hline 7 & 74 & $\mathrm{~m}$ & $\mathrm{AB}$, skin & 2 & 376 & $\mathrm{HF}$ \\
\hline 8 & 58 & $\mathrm{~m}$ & UA, skin & 0 & 239 & $\mathrm{HF}, \mathrm{Ch}$ \\
\hline 9 & 68 & $\mathrm{w}$ & $\mathrm{UA}, \mathrm{AB}$ & 0 & 146 & $\mathrm{HF}$ \\
\hline 10 & 64 & $\mathrm{~m}$ & $\mathrm{UA}, \mathrm{AB}$ & 4 & 689 & $\mathrm{HF}, \mathrm{GRP}, \mathrm{GS}, \mathrm{Ch}$ \\
\hline 11 & 69 & $\mathrm{w}$ & $\mathrm{UA}, \mathrm{AB}$ & 4 & 51 & $\mathrm{HF}$ \\
\hline 12 & 46 & $\mathrm{w}$ & $\mathrm{UA}, \mathrm{AB}$, skin & 2 & 27 & $\mathrm{HF}$ \\
\hline 13 & 73 & $\mathrm{~m}$ & $\mathrm{UA}, \mathrm{AB}$ & 0 & 156 & $\mathrm{HF}, \mathrm{Ch}, \mathrm{L}$ \\
\hline 14 & 49 & $\mathrm{w}$ & $\mathrm{AB}$ & 3 & 789 & $\mathrm{HF}$ \\
\hline 15 & 61 & $\mathrm{~m}$ & UA, skin & 2 & 50 & $\mathrm{HF}$ \\
\hline 16 & 51 & $\mathrm{w}$ & $\mathrm{UA}, \mathrm{AB}$, skin & 3 & 433 & $\mathrm{HF}$ \\
\hline 17 & 48 & $\mathrm{~m}$ & $\mathrm{UA}, \mathrm{AB}$ & 3 & 82 & $\mathrm{HF}$ \\
\hline 18 & 41 & $\mathrm{w}$ & $\mathrm{UA}, \mathrm{AB}$, skin & 3 & 254 & $\mathrm{HF}$ \\
\hline 19 & 62 & $\mathrm{w}$ & $\mathrm{UA}, \mathrm{AB}$, skin & 0 & 210 & $\mathrm{HF}, \mathrm{Ch}$ \\
\hline 20 & 61 & $\mathrm{~m}$ & $\mathrm{AB}$, skin & 3 & 2,883 & HF, GRP \\
\hline 21 & 43 & $\mathrm{~m}$ & $\mathrm{UA}, \mathrm{AB}$, skin & 6 & 1,621 & $\mathrm{HF}$ \\
\hline 22 & 45 & $\mathrm{w}$ & $\mathrm{UA}, \mathrm{AB}$ & 2 & 165 & GB \\
\hline 23 & 53 & $\mathrm{~m}$ & $\mathrm{AB}$ & 0 & 1,136 & GB, GS \\
\hline 24 & 57 & $\mathrm{~m}$ & $\mathrm{AB}$ & 2 & 474 & GB \\
\hline 25 & 54 & $\mathrm{~m}$ & UA, skin & 1 & 19 & BA, GRP, GB, GS \\
\hline 26 & 42 & $\mathrm{~m}$ & $\mathrm{AB}$ & 0 & 93 & GRP, GS, GB \\
\hline 27 & 45 & $\mathrm{w}$ & $\mathrm{UA}, \mathrm{AB}$, skin & 0 & 92 & GS \\
\hline 28 & 55 & $\mathrm{w}$ & $\mathrm{UA}, \mathrm{AB}$, skin & 0 & 2 & GB \\
\hline 29 & 60 & $\mathrm{~m}$ & $\mathrm{UA}, \mathrm{AB}$, skin & 1 & 194 & GB \\
\hline 30 & 31 & $\mathrm{~m}$ & $\mathrm{UA}, \mathrm{AB}$, skin & 3 & 1,115 & $\mathrm{HF}, \mathrm{GB}$ \\
\hline 31 & 41 & $\mathrm{w}$ & $\mathrm{AB}$, skin & 4 & 53 & GS \\
\hline 32 & 64 & $\mathrm{~m}$ & $\mathrm{AB}$ & 2 & 52 & GS \\
\hline 33 & 51 & $\mathrm{~m}$ & $\mathrm{AB}, \mathrm{UA}$ & 2 & 214 & GS \\
\hline 34 & 50 & $\mathrm{~m}$ & $\mathrm{AB}, \mathrm{UA}$ & 2 & 751 & GS \\
\hline 35 & 57 & $\mathrm{~m}$ & $\mathrm{AB}, \mathrm{UA}$ & 1 & 139 & $\mathrm{HF}, \mathrm{GB}$ \\
\hline 36 & 67 & $\mathrm{~m}$ & $\mathrm{AB}$ & 0 & 659 & GRP, GB, BA \\
\hline 37 & 57 & $\mathrm{w}$ & $\mathrm{UA}, \mathrm{AB}$ & 1 & 272 & GS \\
\hline 38 & 25 & $\mathrm{~m}$ & $\mathrm{AB}$, skin & 1 & 69 & GB \\
\hline 39 & 41 & $\mathrm{w}$ & $\mathrm{AB}$ & 5 & 669 & GS \\
\hline 40 & 43 & $\mathrm{~m}$ & $\mathrm{UA}, \mathrm{AB}$, skin & 2 & 181 & $\mathrm{~GB}, \mathrm{GS}$ \\
\hline 41 & 35 & $\mathrm{~m}$ & UA, skin & 0 & 152 & GB, GS \\
\hline 42 & 45 & $\mathrm{~m}$ & $\mathrm{AB}$ & 3 & 445 & GS \\
\hline
\end{tabular}

SDS-PAGE characterization of the commercial extracts

In all four commercial extracts, distinct protein fractions with a molecular weight lower than $14 \mathrm{kDa}$ and at about
$14 \mathrm{kDa}$ were observed. In detail two different bands could be separated; additionally two major and several smaller bands were identified between 18 and $25 \mathrm{kDa}$. In all commercial extracts we found bands at 20, 22, 24/25, 28, 55 and $67 \mathrm{kDa}$. 
SDS-PAGE characterization of self-prepared cattle allergen extracts

In the extracts of the different cattle breeds, different bands were separated likewise. Especially at about $14 \mathrm{kDa}$, the extracts of German Brown and German Simmental, Holstein-Friesian, and Red pied showed stronger bands compared to the commercial extracts (data not shown).

In a molecular weight range between 18 and $30 \mathrm{kDa}$, bands at about $24 / 25 \mathrm{kDa}$, about 20 , and $22 \mathrm{kDa}$ were found. These proteins were detected in the extracts of all investigated cattle breeds. Furthermore, smaller bands were separated with a molecular weight of about 30 and $32 \mathrm{kDA}$ which could not be found in the commercial extracts.

At a molecular weight of about $42 \mathrm{kDa}$, especially Simmental and German Brown showed protein bands without corresponding bands in the commercial extracts. In the higher molecular range a smaller protein band corresponding to a molecular weight of about $68 \mathrm{kDa}$ could be found in a number of self-prepared cattle extracts. The investigations did not reveal any striking breed-specific protein bands. Only a small variability could be seen in the intensity of the protein bands among extracts of cattle of the same breed (data not shown).

\section{Detection of allergens (immunoblotting)}

In immunoblot experiments using self prepared (HF, RP, B, $\mathrm{S}$, and C) and commercial cow allergen extracts (A-D), distinct bands were found in all farmers, even in 13 farmers with a negative RAST result. The pattern of the immunoreactions with cow allergens differed between the sera of the various farmers. Bands were observed with molecular weights in the range between $<14$ and $>67 \mathrm{kDa}$; reactivity at $20 \mathrm{kDa}$ was detected in all farmers, although this reaction was not the strongest in every individual. Reactions of proteins were detected in more than $50 \%$ of the farmers at MW 14 , about 30 , about 55 , and about 67 in addition to the described major allergens at 20 and $22 \mathrm{kDa}$.

In all four commercial extracts, two major bands with a molecular weight of 18 and $20 \mathrm{kDa}$ showed a specific reaction with the antibodies in all sera investigated (Figs. 1, 2, 3 , and 4). Some sera showed a reaction with proteins of a molecular weight of about $14 \mathrm{kDa}$ (Fig. 4). Using the serum of a highly cattle-sensitized farmer the reactivity was very high with all four commercial extracts at a MW of about $11 \mathrm{kDa}$ (Fig. 4).

Only in a few cases additional reactivity was seen at MW of 18, 28, 35, and 44 and about $97 \mathrm{kDa}$ with all four commercial extracts. When comparing the different commercial cattle allergen extracts, differences due to $\operatorname{IgE}$ binding capacity were seen especially at MW of 14, 30, 32, $40 / 42,55,67$, and more than $67 \mathrm{kDa}$.

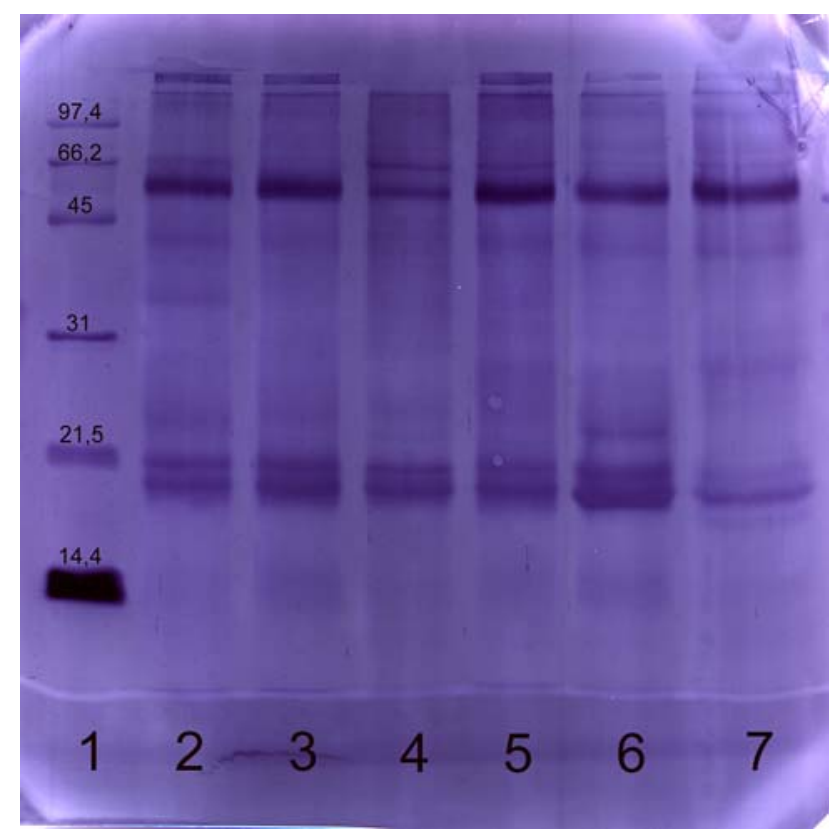

Fig. 1 Immunoblot of commercial and self prepared extract with a human serum (RAST-class 0). Commercial and self prepared extracts were separated using SDS-PAGE, blotted and developed with the serum of a farmer. The following marker and samples were applied: lane 1 molecular weight marker, lane 2 commercial extract $\mathrm{A}$, lane 3 commercial extract $\mathrm{B}$, lane 4 commercial extract $\mathrm{C}$, lane 5 commercial extract $\mathrm{D}$, lane 6 self prepared extract from German Simmental, lane 7 self prepared extract from German Brown. The following amounts of protein were applied: lanes 2-7: $20 \mu \mathrm{g}$

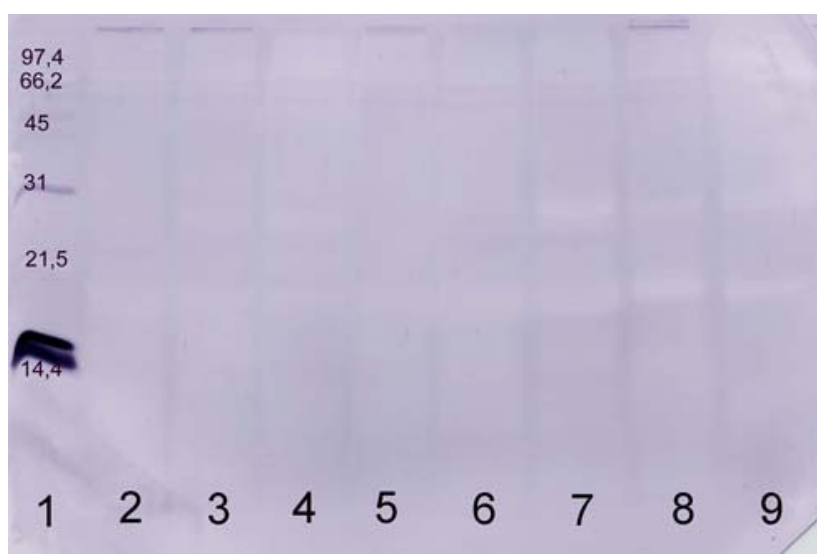

Fig. 2 Immunoblot of commercial and self prepared extract with a human serum from a non-allergic individual. Commercial and self prepared extracts were separated using SDS-PAGE, blotted and developed with the human serum. The following marker and samples were applied: lane 1 molecular weight marker, lane 2 commercial extract $\mathrm{A}$, lane 3 commercial extract $\mathrm{B}$, lane 4 commercial extract $\mathrm{C}$, lane $5 \mathrm{com}$ mercial extract D, lane 6 self prepared extract from German Simmental, lane 7 self prepared extract from German Brown, lane 8 self prepared extract from Holstein-Friesian, lane 9 self prepared extract from German Red Pied. The following amounts of protein were applied: lanes 2-9: $20 \mu \mathrm{g}$ 


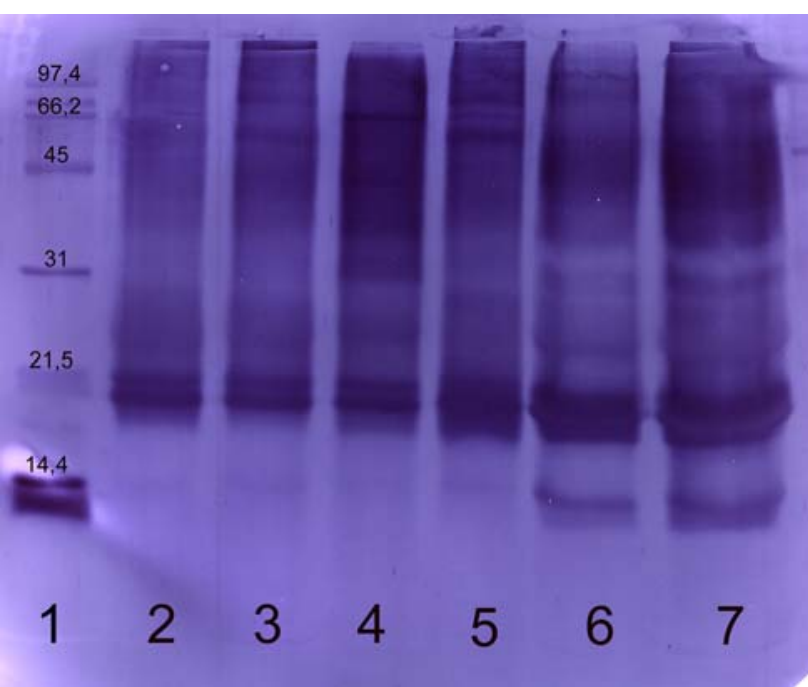

Fig. 3 Immunoblot of commercial and self prepared extract with a human serum (RAST-class 4). Commercial and self prepared extracts were separated using SDS-PAGE, blotted and developed with the serum of a farmer. The following marker and samples were applied: lane 1 molecular weight marker, lane 2 commercial extract $\mathrm{A}$, lane 3 commercial extract $\mathrm{B}$, lane 4 commercial extract $\mathrm{C}$, lane 5 commercial extract $\mathrm{D}$, lanes 6,7 self prepared extract from Holstein-Friesian. The following amounts of protein were applied: lanes 2-6: $20 \mu \mathrm{g}$, lane 7: $60 \mu \mathrm{g}$

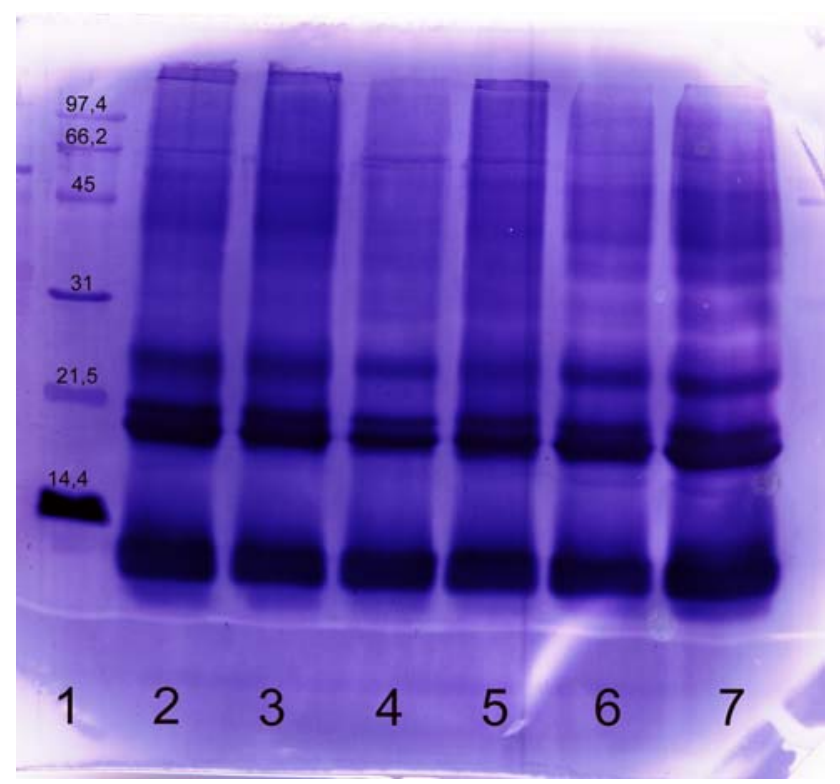

Fig. 4 Immunoblot of commercial and self prepared extract with a human serum (RAST-class 5). Commercial and self prepared extracts were separated using SDS-PAGE, blotted and developed with the serum of a farmer. The following marker and samples were applied: lane 1 molecular weight marker, lane 2 commercial extract $\mathrm{A}$, lane 3 commercial extract $\mathrm{B}$, lane 4 commercial extract $\mathrm{C}$, lane 5 commercial extract D, lanes 6, 7 self prepared extract from German Simmental. The following amounts of protein were applied: lanes 2-6: $20 \mu \mathrm{g}$, lane 7: $60 \mu \mathrm{g}$

In all self prepared cattle allergen extracts, a reaction was observed at MW of 20 and $22 \mathrm{kDa}$. These results corresponded to the results with the commercial extracts. Using extracts of some races small additional reactions were noted at MW of 24/25, 30 and 32, 40/42, about 60, and greater than $97 \mathrm{kDa}$. The self prepared extracts showed reactivity at molecular weights of about 14,55 , and between 66 and $97 \mathrm{kDa}$ in more than 50\% of the farmers. When compared to the results of the commercial extracts a heterogenous reactivity became evident; for example only $5 \%$ of the sera reacted with a band at $30 \mathrm{kDa}$ in commercial extract $\mathrm{C}$ and $\mathrm{D}$ but $35 \%$ with extract $\mathrm{A}$ and $62 \%$ with extract $\mathrm{D}$. The reactions at $\mathrm{MW}$ of $60 \mathrm{kDa}$ and about $11 \mathrm{kDa}$ were the dominant reactions in some of the farmers (Figs. 1, 4). No marked differences were detectable in the sensitisation patterns between the different breeds of cattle (results not shown).

Using the sera of some patients (e.g., Fig. 3) the reactivity at $14 \mathrm{kDa}$ was only shown with the self prepared extract but not with the commercial extracts.

Negative controls, performed without serum and with serum of the two non-sensitized non-farming persons, showed no reactivity in immunoblotting (e.g., Fig. 2).

\section{Bos d 2 quantification}

Hair of eighteen different cattle was investigated, in detail from German Simmental $(n=4)$, Holstein-Friesian $(n=4)$, Red Pied $(n=2)$, Jersey $(n=2)$, German Brown $(n=3)$, Blonde d'Aquitaine $(n=1)$, Charolais $(n=1)$ and Limousin $(n=1)$. The amount of Bos $\mathrm{d} 2$ in the tested hair samples showed a high variability with a Bos d 2 content between $12.2 \mu \mathrm{g}$ and $687 \mu \mathrm{g} / \mathrm{g}$ hair, whereas the Bos $d 2$ content of the hair of individuals of the same races differed up to the 30 -fold. Individual cattle races such as Red Pied $(12.4-59.1 \mu \mathrm{g} / \mathrm{g})$ und Holstein-Friesian (35.7-132 $\mu \mathrm{g} / \mathrm{g}$ ) showed lower levels of Bos $\mathrm{d} 2$ in their hair, while higher Bos $\mathrm{d} 2$ levels were found in the hair of races such as German Simmental (42.9-687 $\mu \mathrm{g} / \mathrm{g})$ und German Brown $(25.8-236 \mu \mathrm{g} / \mathrm{g}$ ). Results are shown in Table 2; races were only considered which were represented by two or more individual cattle.

\section{Discussion}

The purpose of the present study was to assess the multiracial cattle allergens by investigation of the respective protein patterns and their allergological relevance in symptomatic farmers. The Bos d 2 levels in the hair of a range of cattle breeds were also investigated. Special attention was paid to the hypothesis that factors related to distinct cattle breeds were relevant to the allergenicity of cattle, but not sufficiently reflected in commercially available allergological diagnostic tests. 
Table 2 Bos d 2 levels in self-prepared cattle allergen extracts of hair of pure bred cattle of different breed

\begin{tabular}{|c|c|c|c|c|c|}
\hline Breed & $\begin{array}{l}\text { Number } \\
(n)\end{array}$ & $\begin{array}{l}\text { Minimum } \\
\text { Bos } \mathrm{d} 2 \mu \mathrm{g} / \mathrm{g} \text { hair }\end{array}$ & $\begin{array}{l}\text { Maximum } \\
\text { Bos } \mathrm{d} 2 \mu \mathrm{g} / \mathrm{g} \text { hair }\end{array}$ & $\begin{array}{l}\text { Geometric mean } \\
\text { Bos d } 2 \mu \mathrm{g} / \mathrm{g} \text { hair }\end{array}$ & $\begin{array}{l}\text { Median } \\
\text { Bos d } 2 \mu \mathrm{g} / \mathrm{g} \text { hair }\end{array}$ \\
\hline German Simmental & 4 & 42.8 & 687.0 & 340.0 & 314.0 \\
\hline Holstein-Friesian & 4 & 35.7 & 132.0 & 90.0 & 101.0 \\
\hline Red Pied & 2 & 12.4 & 59.1 & 35.8 & 35.8 \\
\hline Jersey & 2 & 12.2 & 357.0 & 184.6 & 184.6 \\
\hline German Brown & 3 & 25.8 & 236.0 & 135.0 & 142.0 \\
\hline
\end{tabular}

Our observation of protein bands at approx. 11, 20, 22, $25,35,55,62$, and $66 \mathrm{kDa}$ as well as several bands in the range between 13 to 17 and 25 to 30 confirm previous studies on the isolation and characterisation of cattle related proteins in different extracts from cow hair and dander (Havass et al. 1971; Löwenstein 1981; Prahl et al. 1978, 1982; Ylönen et al. 1990, 1992a, b; Valero Santiago et al. 1997). We observed a variability of the protein patterns between commercial cattle allergen extracts and the extracts of different cattle breeds. In contrast to our observations with dog allergens (Heutelbeck et al. 2008), the cattle showed only negligible interindividual differences within the same breeds.

Hitherto, several studies have been focused on the differences of cattle allergen extracts that were manufactured using various in vivo and in vitro methods. In crossedimmunoelectrophoresis experiments, extracts of cow hair and dander were found to consist of at least 17 different proteins, based on antigens derived from the pelt of black and white cattle, red Danish milk bred, Danish Jersey breed and Charolais, whereas three major allergenic proteins were identified in cow dander as well as in other tissues and body fluids (Prahl 1981; Prahl et al. 1978, 1982). One of the large protein bands detected in all extracts with an estimated molecular weight of $20 \mathrm{kDa}$ has previously been described as major allergen Bos d 2 (Prahl et al. 1982; Ylönen et al. 1992a, b; Rautiainen et al. 1997). Several studies confirmbesides the $20 \mathrm{kDa}$ allergen-the relevance of the $22 \mathrm{kDa}$ allergen in respiratory cow allergy (Ylönen et al. 1992a, b; Virtanen et al. 1996). In our immunoblotting experiments all cow-allergic patients reacted with these allergens.

Previous reports contained only occasional information on the origin of the different breeds, based on antigens derived from the pelt of black and white cattle, red Danish milk bred, Danish Jersey breed and Charolais (Prahl 1981; Prahl et al. 1978, 1982). In our study several cattle breeds with different characteristics concerning geographical origin, history and development, phenotypic characteristics and genetics were compared. For the first time, races such as German Simmental, Red Pied and German Brown were included. Simmental and Brown are cattle races represented in the whole world; especially Holstein-Friesian is regarded as the most common cattle race worldwide. Therefore we consider it necessary for all relevant allergens of these cattle races to be represented in commercially available cattle allergen extracts.

With regard to the commercial allergen extracts included in our investigations, we could find only minor differences in the protein patterns, in contrast to the quantitative and qualitative differences as well as heterogenic skin test results that had been described previously (Dreborg 1993; Vanto et al. 1980). Yet commercial cattle allergen extracts are a mixture of cattle material such as hair and/or dander from various origins.

At present, the standardization of commercial allergen extracts is focused on only a small number of important allergens such as Bos d 2. Yet in all extracts of the individual cattle of distinct breeds, Bos d 2 has been identified as a allergenic component, However, other proteins also seem to be relevant, such as the bands at MW 14 or MW $55 \mathrm{kDa}$. In consequence, the diversity of the allergen pattern of some breeds was possibly not reflected sufficiently in commercial extracts, when standardization was performed with special regard to the Bos d 2 content.

In the immunoblot experiments we illustrated the comparison of the individual sensitization patterns of cattle allergic farmers using individual as well as commercial cattle allergen extracts. Our results on the $\operatorname{IgE}$ binding are in agreement with previous studies showing reactivity at molecular weights at 11, 15-17, 20, 22, 24, 27, 30, 35, 55, and $62 \mathrm{kDa}$ (Prahl et al. 1978, 1982; Ylönen et al. 1990, 1992a, b; Valero Santiago et al. 1997). Additionally, our results described proteins with allergological relevancebesides the major allergens between 18 and $25 \mathrm{kDa}$-at molecular weights of $14,30,55$, and in the range of $67-$ $97 \mathrm{kDa}$, which reacted with sera of more than $50 \%$ of patients. Our results substantiate the relevance of these proteins which should be reflected in diagnostic cattle allergen extracts.

One of our most striking results was that $32 \%$ of the farmers with cattle related symptoms but negative results with commercial serological tests showed distinct reactions with various cow allergens in the immunoblotting experiments. Therefore we suggest for clinical allergology that 
skin tests should be performed with self-prepared extracts of cattle hair in patients with obviously cow related symptoms.

Besides the lack of certain allergens, another reason for the discrepant results in allergological testing may be that some proteins could have lost their ability to react with IgE antibodies as a consequence of methods of commercial production. Another reason may be the low concentration level of specific allergens in commercial extracts. In order to improve the accuracy of the results of allergen tests in the future, we recommend the inclusion of a greater number of different proteins in addition to the previously presented major allergens in the extracts because of their relevance as demonstrated by our findings.

An individual's response to allergens and the related sensitization spectrum depend on, among others, the chemical nature of the allergens as well as the frequency and intensity of the contact. Bos d 2 levels found in air in the stables may differ (Turowski et al. 2007; Virtanen et al. 1986, 1988, 1992). These variations may be linked to environmental factors such as ventilation or construction details of the cattle stable. They may also be linked to the characteristics of cattle in the stable, such as the number of cattle, or different Bos d 2 distribution of the different cattle breeds.

Concerning this aspect our results show characteristics of the Bos $\mathrm{d} 2$ levels in the hair of the cattle: Certain breeds such as German Brown and Simmental have particularly high quantities of Bos d 2 in the hair. We can confirm that individual factors of the cattle influence the concentration so that the Bos $\mathrm{d} 2$ quantities in the hair can differ extremely, up to 30-fold, between individual animals of the same breed. The hair of cattle races such as Holstein-Friesian and Red Pied showed lower Bos d 2 contents compared to other races. Results of the epidemiological cattle allergy study CAS showed cattle related sensitization in cattle farmers of northern Germany toward cattle races such as HolsteinFriesian in almost the same manner as in regions of southern Germany, which were dominated by cattle races such as German Brown and Simmental with a higher Bos d 2 content (Heutelbeck et al. 2007). Further investigations shall investigate whether other cattle allergens besides Bos d 2 represent the airborne availability of allergological significant cattle allergens more appropriately. Beside environmental influences other factors such as genetic traits, e.g., an atopic predisposition, are relevant for occupational sensitization. We therefore recommend the consideration of not only the occupational environment but also the individual factors of the subjects in the prevention of occupational allergy.

In conclusion several practical consequences can be derived from our experiments: If the results with commercial cow allergen extracts are inconsistent, extracts of own cattle hair should be used in diagnostic immunoblot investigations. A possible lack of relevant proteins in commercial extract may be an explanation for inconsistent results of clinical symptoms and in vivo or in vitro diagnostic methods. In the light of our results, an international standard for cattle hair/dander extracts needs to be discussed, especially with regard to the estimation of the antigen content.

Acknowledgments We are grateful for the support we received in the course of our study. In particular, we would like to thank the Agricultural Institutions for Statutory Accident Insurance and Prevention in Germany and Petra Tucholla, Anke Seeckts and Robert Metzner for technical assistance and editorial support.

Open Access This article is distributed under the terms of the Creative Commons Attribution Noncommercial License which permits any noncommercial use, distribution, and reproduction in any medium, provided the original author(s) and source are credited.

\section{References}

Blanc PD, Jones M, Besson C (1993) Work disability among adults with asthma. Chest 104:1371-1377. doi:10.1378/chest.104.5.1371

Blanc PD, Cisternas M, Smith S, Yelin EH (1996) Asthma, employment status, and disability among adults treated by pulmonary and allergy specialists. Chest 109:688-696. doi:10.1378/chest.109.3.688

Dreborg S (1993) Skin testing. The safety of skin tests and the information obtained from using different methods and concentrations of allergen. Allergy 48:473-475. doi:10.1111/j.1398-9995.1993. tb01102.x

Fuchs E, Gronemeyer W, Bandilla K (1981) Reibtest und Tierhaarallergie, zugleich ein klinischer Beitrag zum Problem der "Rassespezifität”. Allergologie 4:241-248

Havass Z, Osváth P, Endre L (1971) Biochemical studies on allergenic proteins of bovine hair extracts. Allerg Immunol 17:299-306

Heutelbeck AR, Janicke N, Hilgers R, Kütting B, Drexler H, Hallier E, Bickeböller H (2007) German cattle allergy study (CAS): public health relevance of cattle-allergic farmers. Int Arch Occup Environ Health 81:201-208. doi:10.1007/s00420-007-0207-y

Heutelbeck A, Schulz T, Bergmann KC, Hallier E (2008) Environmental exposure to allergens of different breeds of dog and relevance in the allergological diagnostics. J Toxicol Environ Health A 71:751-758

Karjalainen A, Kurppa K, Virtanen S, Keskinen H, Nordmann H (2000) Incidence of occupational asthma by occupation and industry in Finland. Am J Ind Med 37(5):451-458

Löwenstein H (1981) Allergene von Katze, Hund, Rind und Pferd. Allergologie 5:265-269

Prahl P (1980) Isolation of allergens from cow hair and dander. Allergy 35:208-209. doi:10.1111/j.1398-9995.1980.tb01748.x

Prahl P (1981) Allergens in cow hair and dander. Allergy 36:561-571. doi:10.1111/j.1398-9995.1981.tb01874.X

Prahl P, Weeke B, Löwenstein H (1978) Quantitative immunoelectrophoresis analysis of extract from cow hair and dander. Allergy 33:241-253. doi:10.1111/j.1398-9995.1978.tb01544.x

Prahl P, Bucher D, Plesner T, Weeke B, Löwenstein H (1982) Isolation and partial characterisation of three major allergens in an extract from cow hair and dander. Int Arch Allergy Appl Immunol 67:293-301

Rautiainen J, Rytkönen M, Virtanen T, Pentikäinen J, Zeiler T, Mäntyjärvi R (1997) BDA20, a major bovine dander allergen characterized at the sequence level, is Bos d 2. J Allergy Clin Immunol 100:251-252. doi:10.1016/S0091-6749(97)70232-X 
Reijula K, Patterson R (1994) Occupational allergies in Finland in 198191. Allergy Proc 15:163-168. doi:10.2500/108854194778702919

Turowski S, Baur J, Seeckts A, Lange M, Metzner R, Scheuermann H, Hallier E, Heutelbeck A (2007) Charakterisierung der Rinderallergenexposition in Niedersächsischen und BadenWürttembergischen Rinderstallungen. Verh Dt Ges Arbeitsmed Umweltmed 47:500-502

Valero Santiago AL, Rosell E, Lluch M, Sancho J, Piulats J, Malet A (1997) Occupational allergy caused by cow dander: detection and identification of the allergenic fractions. Allergol Immunopathol (Madr) 25:259-265

Vanto T, Viander M, Koivikko A (1980) Skin prick test in the diagnosis of dog dander allergy: a comparison of different extracts with clinical history, provocation tests and RAST. Clin Allergy 10:121-132. doi:10.1111/j.1365-2222.1980.tb02089.x

Virtanen T, Louhelainen K, Mäntyjärvi R (1986) Enzyme-linked immunosorbent assay (ELISA) Inhibition method to estimate the level of airborne bovine epidermal antigen in cowsheds. Int Arch Allergy Appl Immunol 81:253-257

Virtanen T, Vilhunen P, Husman K, Happonen P, Mäntyjärvi R (1988) Level of airborne bovine epithelial antigen in Finnish cowsheds. Int Arch Occup Environ Health 60:355-360. doi:10.1007/ BF00405670

Virtanen T, Eskelinen T, Husman K, Mäntyjärvi R (1992) Long- and short-term variability of airborne bovine epithelial antigen concentrations in cowsheds. Int Arch Allergy Immunol 98:252-255
Virtanen T, Zeiler T, Rautiainen J, Taivainen A, Pentikäinen J, Rytkönen M, Parkkinen S, Pelkonen J, Mäntyjärvi R (1996) Immune reactivity of cow-asthmatic dairy farmers to the major allergen of cow (BDA20) and to other cow-derived proteins. The use of purified BDA20 increases the performance of diagnostic tests in respiratory cow allergy. Clin Exp Allergy 26:188-196. doi:10.1111/j.1365-2222.1996.tb00079.x

Wortmann F (1984) Sensibilisierungen gegenüber Haaren und Epithelien verschiedener Tierindividuen (bei fraglicher Rasseidentität)- Bedeutung der Testung mit Material des patienteneigenen Allergenspenders. Allergologie 7:69-73

Ylönen J, Nuutinen J, Rautiainen M, Ruoppi P, Mäntyjärvi R, Virtanen $\mathrm{T}$ (1990) Comparative analysis of bovine extracts by immunoblotting and ELISA inhibition. Allergy 45:30-39. doi:10.1111/ j.1398-9995.1990.tb01081.x

Ylönen J, Mäntyjärvi R, Taivainen A, Virtanen T (1992a) IgG and IgE antibody responses to cow dander and urine in farmers with cowinduced asthma. Clin Exp Allergy 22:83-90. doi:10.1111/j.13652222.1992.tb00118.x

Ylönen J, Mäntyjärvi R, Taivainen A, Virtanen T (1992b) Comparison of the antigenic and allergenic properties of three types of bovine epithelial material. Int Arch Allergy Immunol 99:112-117

Zetterström O, Johansson SGO (1981) IgE concentrations measured by PRIST in serum of healthy adults and in patients with respiratory allergy. A diagnostic approach. Allergy 36:537-547. doi:10.1111/j.1398-9995.1981.tb01871.x 